\title{
BANQUETS AND POWER: \\ BOIARDO'S INNAMORATO AND THE POLITICS OF GASTRONOMY
}

\section{PINA PALMA}

Power shapes people's social and political consciousness and, although it rarely reflects a consciousness of self, it is ever mindful of the privileged modes to which it is entitled. It can be displayed through a variety of means, all of which are a deliberate expression and consolidation of grandeur and authority. Foodstuffs as a socio-political metaphor lend itself quite naturally as a tool carving social identity. Aristotle in his Politics (1256a) characterizes the consumption of different foodstuffs in terms of the dissimilar "ways of life" that it produced. The terms of his argument appear inverted in the Renaissance when sophisticated lifestyles were believed to require the consumption of refined food. As we know from extant treatises, the culture and mentality of self-indulgent court life favoured a diet based on rare delicacies elaborately prepared. This type of dietary conventions defined social identity and, by emphasizing cultural divisions and social hierarchy, it effectively conferred a status-building trait to gastronomy. For this reason, the staging of stupendous banquets in Renaissance Italy became another vehicle to express princely power. Through these lavish productions that ensured self-aggrandizement, princes marked social as well as religious events, political alliances, and special loyalties.

For these occasions professional cooks transformed exotic ingredients into delicate morsels and elaborate dishes that suited the sophisticated palates of the upper class. Exquisite concoctions, prepared according to dietetic norms dispensed by highly regarded court doctors and humanists, translated the host's power into gastronomic spectacles that validated, and even magnified, his grandeur. As a coded but calculated language of persuasion food ingratiated the host to the guests, and this, in turn, enabled him to seize opportunities and capitalize on the advantages that the perception entailed. The political overlay superimposed to these convivial gatherings cannot be ignored, for it is precisely because of the political implications that food transmits through its "metaphorical or symbolic qualities," that banquets turned the host's private ambitions into public spectacles. These elaborately choreographed gastronomic manoeuvres daz- 
zled the guests and cemented the host's shrewdness and credibility, though not necessarily his competence and integrity as a leader.

The banquet staged in 1473 by Sisto IV's nephews Giuliano della Rovere and Pietro Riario to welcome Eleonora D'Aragona in Rome is a cogent illustration of gastronomic politics. Riario took intense interest to ensure that before departing for Ferrara, where she was to become the wife of Ercole I, Eleonora and the duke's envoys, with Matteo Maria Boiardo among them, were entertained with unprecedented magnificence. In the house he erected in her honour near the Church of the Holy Apostles, Cardinal Riario's wealth, power, and sophistication were meticulously displayed. Splendid furnishings, new theatrical representations and an opulent banquet left their mark on his prestigious guests (Pastor, 241-244). Letters written by ambassadors, as well as by Eleonora herself, corroborate Riario's reputation as a powerful and astute statesman. That Riario transformed the banquet into a formidable political manoeuvre is confirmed by the successful achievement of his immediate objective: offering a public display of the pope's alliance with the Aragonese king and, of course, Duke Ercole, while simultaneously casting off the Orsini and Medici families. By astutely turning the political discourse into one of gastronomic seduction and, at the same time, by fusing the two into one ingenious triumph, Cardinal Riario gave new meaning to the Renaissance understanding of political strategizing. His deliberate substitution of a symbolically rich meal to a series of predictable political gestures demonstrated Riario's uncanny awareness of the possibilities offered by commensal diplomacy. He showed, among other things, that to influence people of power, diplomatic skilfulness must rely on, and permeate, every social activity in which those people took pleasure. At the same time, however, his act demonstrated that if on the one hand eating at his table signalled the renewal of papal-Aragonese diplomatic relations, it, on the other hand, also denoted the moral and ethical shortcomings of the parties partaking of the meal. The Cardinal's banquet, as a carefully conceived means to promote papal interests, served as a stage for the porous and ambivalent relationship between the pope's power and the fickle nature of his political alliances, but left no space for Christian ethical values.

The three-course menu included stags roasted whole in their skins, goats, hares, calves, herons, peacocks with their feathers, and a bear: ostentatious dishes for a self-conscious group. Meats were served covered in silver and innumerable sweets and confectionary shaped into artistic tableaux intended to stir and conquer the onlookers' imagination ensured the triumph of appearance. However, despite-or perhaps because of - its adher- 
ence to the aristocratic culinary code, the far-reaching political implications of Riario's banquet served more as an attack on his enemies than as a praise of his new allies. An illustration of this is the bear meat. Prized for its rarity rather than its nutritional qualities - because, according to the Galenic humoral theory, it "is not good for spleen or liver" and "generates all kinds of indigestible residue," as Platina's De Honesta voluptate et valetudine explains (Platina, 236-237) - this animal implicitly evokes not only the hunt for, but especially the overpowering of a fiercely untamed force. The political message couched in the spectacle of a bear reduced to a meal could also call to mind the powerful Orsini family, ${ }^{1}$ the pope's embittered rivals, linked by marriage to the Medici. Playing both on the homonymy and the meat's symbolic value, Riario insinuated the idea of the Orsini's subjugation and downfall so that his guests could foretaste, savour in fact, the political and economic results of such political a feat. Platina's treatise emphasizes the weakness of the bear's head and contrasts it to the strength of the lion's. Accordingly, Riario's presentation of a "conquered" bear enhanced, by contrast, the leonine power that the Della Rovere, Aragonese, and Este families embodied. This bold act of gastronomic politics, suggesting that even untamed nature could be reduced to submissiveness through resolute forces, in fact literally and metaphorically swallowed, could hardly escape Riario's guests.

In the Orlando Innamorato the interplay between power and banquets emerges in the very first canto of the poem. As he presides over a Pentecost banquet surrounded by his knights, Charlemagne incarnates power. A truce he has declared for the occasion allows the Saracens to partake of the meal. The symbolism of Pentecost, recalling the Holy Spirit that-during a meal-emboldened and empowered the apostles to speak in foreign tongues and sway non-believers by proclaiming the new covenant, is here ostensibly retrieved through Charles' invitation to the Saracens. The image of enemies sharing food infuses a symbolic value of sacredness into the scene and imbues it with the notion of power that transcends - and unites -warring factions. This power, which has the capacity to suspend momentarily the reality of war and gather enemies at the same table, effectively redraws the boundaries of Charles' authority and relegates the Saracens to a position of passive power. Although on the battlefield they personify the force that opposes Charles, at the banquet, as his guests, they temporarily if unwittingly recast themselves in the role of his deferential subjects while he, paradoxically, assumes that of their sovereign because of

${ }^{1}$ I am grateful to Giuseppe Mazzotta for first suggesting this possibility. 
the food he provides. By temporarily turning into the "nourishing emperor," fusing chivalric largesse with seeming Christian generosity, Charles, like Riario, forges a link between food and peace that conceals the chasm between the host's misleading generosity and the guests' indebtedness.

As the gastronomic translation of his power, Charles' banquet brings the stranger, the "other," the adversary into the fold, transforming it into the familiar, friendly commensal. In their temporary transformation the Saracens are juxtaposed to the impermanence that food represents. "Finissime vivande" in fact require creating something new from old forms and hinges on the process of transforming even decayed ingredients into something appetizingly fresh and new. Ingredients blended together transform the "vivande" and produce gastronomic results that retain the flavours, but not the shapes, of original components. Culinary creations herald new and unforeseeable gastronomic reconfigurations. Unlike other transformations, however, food transforms the transformed and from deterioration reproduces dishes that in their transient quality mirror the consumer's impermanent nature, fixing, even wriggling it against the permanence of history. The constructive process that food exemplifies suggests at first glance a correspondence with the new role the Saracens play at Charles' table. A rupture in this occurs, however, as the terse exchange between Rinaldo and King Balugante takes place. This reveals that despite the superficial display of kindness, deep-seated hostility is not appeased through hypocritical celebrations of religious feasts. The banquet displays Charles' power and the influence he has over his guests, suggesting that Saracens, like "finissime vivande," can be consumed, devoured, by French knights.

Ridiculed by the Saracens for the modesty of his clothes, Rinaldo conceals the resentment that gnaws him and savours the thought of revenge he believes will be his the next day at the joust. Balugante, however, detects his uneasiness and further humiliates Rinaldo by asking him whether the court honours him for his virtues or his possessions. Although the immediate goal is to deride the knight, Balugante's question implicitly casts doubt on his hosts' moral and ethical values. By raising the issue of appearance versus substance, hypocrisy versus sincerity, the pagan king unwittingly strips the veneer of hospitality the banquet seeks to sustain and exposes it as a banal ritual lacking the true spirit of the event it seeks to reenact. The contempt in which the Christians hold the Saracens and their customs transpires in the manner in which they are described at the banquet. The verse that depicts them as "Saracini che non volsero usare banco né sponda,/ Anzi sterno a giacer come mastini/ Sopra a tapeti, come è loro 
usanza," (1, 13:4-6) scorns the Saracens' custom of eating on rug-covered floors. Commensal hierarchy that places higher-ranking individuals at tables raised on platforms is rooted in court protocol governing the practices and observances of ceremonial banquets. By consuming the meal on the floor, as they customarily do, the Saracens implicitly relinquish the position of power that seating at the table would afford them and further the onlookers' perception of their social and moral inferiority. But more than this, their custom dehumanizes them in the eyes of the Christians. The lower space the Saracens choose to occupy at the banquet makes it possible for the Christians to liken them to mastiffs, the aristocracy's dogs of choice that usually lie below the tables waiting to eat scraps tossed to them. This image of men eating below the tables, in front of Charlemagne, constructs a social vertical scale of commensal hierarchy that again places Saracens at the bottom and the French at the top of it.

Rinaldo is not any more sympathetic toward the Saracens for he calls them "gente asinina, maledetta razza" $(1,16: 6)$. His opinion is based on a construction of the "otherness" that excludes a priori the possibility of acceptance and inclusion because this would entail the acknowledgment and tolerance of cultural variables and, more importantly, the acceptance of the ambiguities and tensions that are inherent in human interactions among individuals from different belief systems. Rinaldo denigrates the Saracens for their lack of intelligence. His generalization is based solely on the affected construct of what he sees around him rather than on his direct experience. Still, more forcefully than Rinaldo's, Charles' remarks about his guests illustrate not just the cultural dichotomy between the two groups, but especially the contradictions undermining the meal's true meaning. The assertion that the emperor "tutta la gente pagana disprezza, / Come arena del mar denanti a i venti" $(1,20: 6-7)$, reveals the full measure of Charles' disdain toward those he presumes inferior-in strength and knowledge - to him. As he retrieves the biblical image of sand blown by forceful wind, Charles inverts the meaning of the Psalm² where man's vulnerability is counterbalanced by God's compassion and discloses, instead, his misplaced sense of superiority toward men he perceives as weaker.

Predictably, Rinaldo does not take kindly to being publicly mortified. His retort to Balugante, however, shows him in control of his simmering resentment and even able to maintain an ostensibly unaffected behaviour

2"So the Lord has compassion on those who fear him... He remembers that we are dust...Man's days are like those of grass... The wind sweeps over him and he is gone, and his place knows him no more," Psalm 103, 13-16. 
without submitting to impulsiveness. By explaining that Christians indulge gluttons at the tables, pamper whores in beds, and confer honour only according to courage, Rinaldo defines his cultural understanding of appearances and substance. According to this logic, gluttons who ravenously devour and who are at the same time devoured by the rapacity of their desires are appeased and subjugated by the French according to their want. Prostitutes, like gluttons, are enslaved by and succumb to the perversion of desires that makes them vulnerable preys in the hands of shrewd pursuers. Rinaldo's argument, pairing gluttons and prostitutes, hinges on the deep-rooted Christian belief that from Post-lapsarian times linked the seductiveness of eating to sexual seduction. But as it fuels tension by casting the Saracens as voracious destroyers of traditions and conventions, willing to prostitute moral and ethical standards for material gains, Rinaldo's powerful indictment unveils the hypocrisy saturating his (and the Christians') system of beliefs. While he argues that honour at his court is a measure of one's courage, his argument exposes deeper chords that resonate with his and his people's failure to understand that courage cannot be gauged by using flawed models. The conscious, careful, and single-minded depravity necessary to preying on gluttons and prostitutes' weaknesses discloses in fact the perpetrators' cowardice. By depicting his fellow knights as men skilled at gratifying the wants of individuals incapable of self-control in return for personal gains, Rinaldo ascribes to his faction the same deceitfulness and depravity for which he faults the Saracens. Accordingly, his rationale for honour fizzles out, leaving only the shell of his argument to prove the validity of the honour system that governs his camp. The emptiness of Rinaldo's argument reflects the ostentatious celebration of Pentecost. Reduced to a display of mere aesthetic significance the celebration of the Christian feast crumbles into a ritualization of forms that are disconnected from spiritual meaning. Christian beliefs paraded into spectacles of power to aggrandize Charles' power in the Saracens' eyes suggest only the prostitution of moral and ethical principles. The evisceration of the very principles on which the Christian camp supposedly bases its foundations necessarily entails the exclusion of honour. Rinaldo's scathing but flawed remark with regard to honour shows both his unawareness of the subtle implications his own argument presents and his failure to recognize the facts as they present themselves at the banquet.

Still, Balugante's insinuation juxtaposing wealth and courage indirectly exposes the moral inconsistencies cultivated by the sophisticated court culture. From this perspective the banquet's refined "vivande," transformed through intricate preparations of ingredients, is the symbolic correspon- 
dent of a mode of conduct that favours appearance over substance. The banquet's encoded meanings reveal only hypocritical interactions between Christian and Saracens. And, as the space where commensal politics take place to seduce the enemy, render it harmless, and even temporarily turn it into an obliging ally, Charles's banquet is the literary counterpart to Riario's Roman feast. Like the historical one, rather than marking the partakers' moral and ethical integrity, this banquet denotes their unscrupulous practices. Or, to put it differently, under the veneer of conventional JudeoChristian symbolism both banquets provide a view into the partakers' covetousness for power: power of possessions, power of wealth, and power to enforce particular perspectives. In short, they provide images of material (and carnal) desires that the partakers yearn to gratify.

The "finissime vivande" served at Charles' banquet do not reveal any specific content of the meal. Yet Boiardo's familiarity with the Este court and its customs, as well as the banquet's description, unequivocally suggests that Charles' meal hinges on the gastronomy of power. Still, it is surprising that the poet is not more precise because what may appear as a trifling non-issue becomes relevant when compared to the wider context of the Innamorato. In other cantos the poet is very specific about the food his characters consume. In Canto XXV, for example, Angelica welcomes Rinaldo's cousin Orlando to a meal that specifically includes "frutti e confetti di molta ragione" $(1,25: 46)$. During the meal she seduces and renders him harmless to the point that he becomes unable to achieve the goal that has set him on his journey: namely, possessing her. Angelica's confetti not only render Orlando powerless, but they also turn him into her pawn, a condition that can arguably be described as his becoming her food. Given the details Boiardo offers in other cantos, it stands to reason to believe that by not using the same accuracy in the crucial first canto the author gives "vivande" a broader meaning than food. And if one accepts the idea that despite their masterful preparations "vivande" are ultimately consumed, and destroyed by those who eat them, it is also possible to believe that they stand as a metaphor for human beings.

According to Louis Marin, through the process that transforms raw ingredients into prepared dishes, food becomes a sign encompassing elaborate ideological, political, and cultural concepts. He argues that it is through this metamorphosis that the comestible is transformed into the signified and the speakable is transformed into the edible (Marin, 125). Marin notes that in its resulting function of "transsignificance," (Marin, 122) food becomes a metaphor, acquiring new meanings completely disassociated from its original physical significance. Marin's argument is espe- 
cially relevant to Boiardo's lack of specificity for this first banquet and the way he cuts it short by interjecting Angelica's arrival into it. She disrupts the banquet and wrecks havoc among Christians and Saracens. Everyone's attention turns to her and she, with her tale, captivates all. Putting the food as well as their differences out of their minds, both Christians and Saracens inflamed by desire hunger for Angelica and long to have her, that is, to consume-eat-her. By seizing their attention and supplanting the "vivande," she effectively becomes a "vivanda" each man believes can be appropriated for his individual pleasure. But just as the "vivande" turned powerful enemies into obliging guests, this new "vivanda," Angelica, turns her foes into submissive subjects.

Charles himself is not impervious to the power she exerts and agrees, without much consideration, to the terms of her request. Although Angelica's true intentions are hidden from him at this time, his lack of concern with the accuracy of her story reveals, like his banquet, his fascination with form rather than substance. This appears most conspicuously in the verse that describes him as one who "Mira parlando e mirando favella." The image of the aloof, focused leader is here countered with one that exposes a man mesmerized by, and vulnerable to, the attractiveness of his interlocutor. "Mirare," which means both "to look" and "to admire," sums up Charles' susceptibility to Angelica's beauty. But it is his "parlare" that turns into "favellare," suggesting a shift from self-controlled to unguarded and even fantastic conversation, that more precisely sums up his capitulation to her. As the flaws of his character surface, Charles' role as the moral and political leader becomes questionable. He turns into Angelica's pawn and, as a result, the power he imperiously embodied and displayed through his banquet teeters on the brink of powerlessness and subjection. The scrumptious but unspecified "vivande," the bait with which he temporarily disempowered the Saracens, finds its correspondent in Angelica (the Saracen) who renders the emperor Charles, like all the men around him, powerless. The scale of commensal hierarchy is here turned upside down by Angelica, a Saracen and a woman who embodies the unexpected and unspecified "vivanda" capable of thrusting the emperor and his knights into a position of passive power.

We know that by relying on the politics of food Riario succeeded in imposing his interests on his guests, essentially redesigning, if only for a brief period, the political map of early modern Italy. The Pazzi conspiracy that would expose the Riario / Della Rovere plotting was to backfire only in 1478. By this time Cardinal Riario was dead and Sisto's manoeuvrings had already entered a more complex stage. Yet Boiardo, the ambassador- 
poet who attended Riario's historical banquet and had first-hand experience with gastronomic politics, does not afford the same success to his characters. Time and again he questions and undermines the legitimacy not just of their personal interests, but the means by which they seek to achieve them. He questions their obsession with rules and decorum and also their inability to confront embarrassing truths. In canto one Rinaldo and Charles, blind to what they perceive to be both irrelevant and extraneous to their moral superiority, do not question the principles on which they base their certainty. As a conduit for exposing the duplicity, ambiguity, and limits of power devoid of self-analysis food and banquet serve Boiardo formidably in the first Canto of the Innamorato. They show that despite the sense of aloofness and control their cultivated images seek to convey, powerful individuals who lack a clear sense of introspectiveness, like elaborate "vivande," conceal their true moral character under visual and ideological self-serving disguises. This, of course, raises a more intriguing question: is this Boiardo's critique of the Este's elite circle within which he worked? Or is it, again, just a matter of a persuasive woman appearing at the wrong time and making an offer that no reasonable man could possibly decline?

\section{Southern Cconnecticut State University}

\section{Cited Works}

Aristotle. The Complete Woks of Aristotle. Ed. Jonathan Barnes. Princeton, N. J.: Princeton UP, 1984. 2 vols.

Boiardo, M. M. Orlando Innamorato. Ed. R. Bruscagli. Turin: Einaudi, 1995. 2 vols.

Marin, Louis. Food for Thought. Trans. Mette Hjort. Baltimore: The Johns Hopkins UP, 1989.

Messisbugo, Cristoforo. Libro Novo: Nel qual sinsegna a far d'ogni sorte di vivanda secondo la diversità dei tempi, così di carne come di pesce. Et il modo d'ordinar banchetti, apparecchiare tavole, fornire palazzi, e ornar camere per ogni prencipe. Venice: al segno di San Girolamo, 1556.

Pastor, L. F. The History of the Popes, from the Close of the Middle Ages. Ed. F. I. Antrobus. London: Routledge \& Kegan Paul Ltd, 1949. 40 vols.

Platina. De honesta voluptate et valetudine. Ed. and trans. M. E. Milham. Tempe, AZ: Medieval and Renaissance Texts \& Studies, 1998.

Savonarola, Michele. Libretto de tutte le cosse che se magnano: Un'opera dietetica del secolo XV. Ed. Jane Nystedt. Stockholm, Sweden: Almqvist \& Wikswell International, 1988. 